\title{
Sertoli-Leydig Cell Tumor (SLCT) of the Ovary - A Case Report
}

\author{
MST. MOONMOON BEGUM ${ }^{1}$, FERDOUSI SULTANA ${ }^{2}$
}

\begin{abstract}
:
Sertoli-Leydig Cell Tumor (SLCT) is an extremely rare and distinctive sex cord-stromal tumor. Ovarian sex cord-stromal tumors are infrequent tumors that differ from the more frequent epithelial neoplasm and have strong association with hormone-mediated syndromes, presentation in a wide age range, and the diagnosis is usually at early-stage disease with a good outcome. SLCT typically present with pelvic or abdominal pain and tenderness, mass, and or abnormal menstruation, and with hormonal activity reported predominantly after menarche. We report a case of 18-year-old unmarried female presented with severe pain and lump in the lower abdomen. She was a case of primary amenorrhea with normal secondary sex characters. She was a suspected case of twisted ovarian tumor on USG and underwent laparotomy followed by total excision of the lump and histopathology report revealed Sertoli-Leydig Cell Tumor. Though it is a rare tumor, the possibility of Sertoli-Leydig Cell Tumor in a young woman should be kept in mind.
\end{abstract}

Key Words: Ovarian tumor, Sclerosing stromal tumor, sex cord-stromal tumor, SertoliLeydig Cell Tumor.

\section{Introduction:}

Ovarian sex cord-stromal tumors are uncommon neoplasms that represent approximately $7 \%$ of all ovarian tumors ${ }^{1}$. These tumors comprise a heterogeneous group and are formed by diverse cell types that arise from the primitive sex cords or stromal cells ${ }^{1-2}$. The stromal cell includes theca cells, fibroblasts, and Leydig cells whereas the gonadal primitive sex cords include granulosa cells and Sertoli cells $^{3}$. These cell types may be present separately or admixed and display different degrees of differentiation ${ }^{4}$.

Sertoli-Leydig Cell Tumor is an extremely rare ovarian neoplasm that accounts for approximately $0.5 \%$ of all ovarian neoplasm ${ }^{3-5}$. According to WHO classification scheme for ovarian sex cord-stromal tumors (2014), it is included in the mixed sex cordstromal tumors which may be well-differentiated to poorly- differentiated with heterologous elements, and retiform with heterologous elements.
Approximately $75 \%$ of the SLCTs are encountered in women of younger age usually less than 30 years ${ }^{6}$. However, few cases have been described in postmenopausal women ${ }^{7-8}$. For SLCT, nearly all cases are unilateral $(98 \%)$ and $80 \%$ are confined to ovary at diagnosis ${ }^{4-5}$.

SLCT is the most common virilizing tumor, as approximately $30-50 \%$ of these tumors produce androgens (testosterone \& androgens precursors) and more than one-third of cases develop symptoms of virilization and amenorrhoea ${ }^{4,5,9}$.

Notwithstanding, SLCT is a rare cause of virilization in premenopausal women. In this age group, other differential diagnosis such as PCOS and adrenal androgen producing tumors should be considered.

Many SLCTs are hormonally inactive and a small sub group is estrogenic. Sudden abdominal pain and swelling are frequent symptoms of non-functioning tumors.

1. Resident Surgeon, Obstetrics \& Gynecology, Rangpur Medical College Hospital, Rangpur.

2. Head of the Department of Obstetrics \& Gynecology, Rangpur Medical College Hospital, Rangpur.

Address of Correspondence: Dr. Mst. Moonmoon Begum, Resident Surgeon, Rangpur Medical College Hospital, Email: munmun.ahmed@yahoo.com, Mobile: 01712-263846. 
Very rarely, SLCT have been reported to associate with elevated alpha-fetoprotein serum levels; this is a typical feature of germ cell tumors such as yolk sac neoplasm.

The prognosis of SLCT is good and $92 \%$ of tumors manifest at early stage i.e. at stage $-1^{6}$. The most important prognostic factors are the stage and degree of histologic differentiation $3,6,10$. In a previous report by Sigismondi et al., five year survival rates of $92.3 \%$ and $33.3 \%$ were reported for patients with stage 1 and stage e" 2 disease, respectively ${ }^{11}$. In the same report, patients with well-differentiated tumors had a five-year survival rate of $100 \%$ versus $77.8 \%$ for patients with moderately and poorly differentiated tumors.

In contrast to Germ Cell Tumors, which tend to recur late, malignant SLCTs usually recur early in the pelvic and abdominal cavity. With a reported relapse rate of $71.4 \%$ within two years after diagnosis ${ }^{11}$.

\section{Case Report:}

An 18-years-old unmarried girl was admitted in the in-patient department of obstetrics and gynecology of Rangpur Medical College Hospital with the complaints of severe pain and lump in the lower abdomen. Her menstruation has yet not established. On clinical examination, she was $162.5 \mathrm{~cm}$ tall, weight $50 \mathrm{~kg}$, B.P $100 / 60 \mathrm{~mm}$ of $\mathrm{Hg}$, breasts were developed, and axillary and pubic hair were present and female type of distribution, and external genetalia and introitus were present. A tender mass of about $10 \times 9 \mathrm{~cm}$ was palpable in lower abdomen; surface was irregular with ill defined margin and restricted mobility. Bimanual examination was done gently with one finger: cervix was absent and uterus could not be well delineated. Digital Rectal Examination also done gently and findings correspond with that of bimanual examination. Ultrasonography (USG) revealed that size and shape of the uterus was not well defined and a well defined complex, predominantly solid mass with small cystic component of about $(108 \times 93) \mathrm{mm}$ is noted in left adnexal region. Tumor markers could not be done due to shortage of time as it was an emergency. On laparotomy, uterus could not be delineated rather it was found as a fibrosed band like structure. Both sided fallopian tubes were present and a partly solid and partly cystic mass of about $(10 \times 10) \mathrm{cm}$ was found on the right adnexal region which was adherent with fibrosed band and omentum but left ovary could not be visible separately which may be buried or adherent with right ovarian mass. There was no acsites. After total excision of the mass, both the fallopian tubes, fibrous band was also removed and partial omentectomy was done (which was apparently healthy looking i.e. no seedling or cake like feelings), and specimens were sent for histopathology. Postoperative period was uneventful and the patient was discharged on $5^{\text {th }}$ postoperative day.

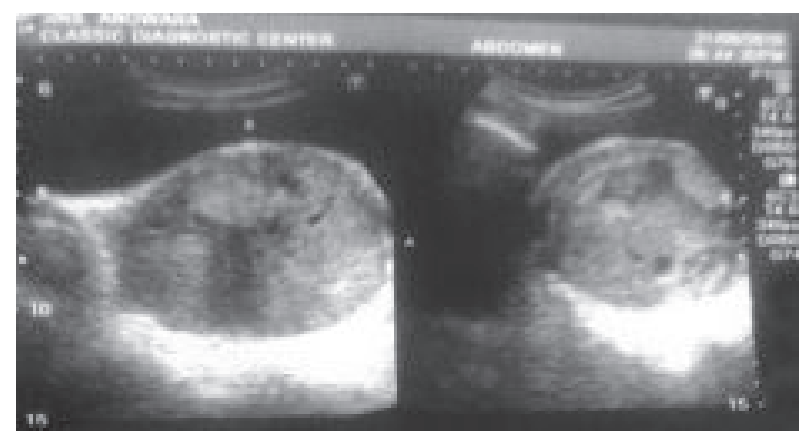

Fig.-1: Ultrasonography showed a well defined complex predominantly solid mass with small cystic component about (108x93) $\mathrm{mm}$ is noted in left adnexal region compressing the uterus.

Histopathological report of the mass showed features compatible with Sertoli-Leydig cell tumor with area of necrosis and calcification.

Histopathology of omentum showed edematous and congested fibro fatty tissue with focal mesothelial proliferation and infiltration of inflammatory cells.

\section{Discussion:}

Sertoli-Leydig Cell Tumor is mixed sex cord-stromal tumor, described as a distinct entity in 1973 by Chalvardjian and Scully ${ }^{12}$. Ovarian Sex cord stromal tumors are uncommon neoplasm that represents approximately $7 \%$ of all ovarian tumors ${ }^{1}$ and SLCT comprises less than $0.5 \%$ of all ovarian tumors. This extremely rare tumor characteristically differentiates itself from others both clinically and histologically. The reported mean age is $23-25$ years in different studies $^{13}$. The well-differentiated tumors occur at an average age of 35 years and retiform tumors at an average age of 15 years ${ }^{14}$.

About one third of patients with SLCT have androgenic manifestations including: oligomenorrhoea, hirtutism, hoarseness, breast atrophy, and clitoral hypertrophy. Approximately half of patients with SLCT have no endocrine manifestation and mainly experience 
abdominal swelling and pain. Occasional patients have been represented with estrogenic manifestation, including irregular menstruation or menorrhagia in women in the reproductive age group and postmenopausal bleeding in older women. Welldifferentiated SLCTs accounts for about $10 \%$ of all SLCTs. There is a statistical association with congenital anomaly of the internal genitalia in otherwise normal women and with testicular feminization syndrome ${ }^{15}$. Grossly these tumors are usually unilateral, solid, well-circumscribed, yellow, firm and lobulated masses of 5-6 cm average size. The cut surface shows hemorrhage and cystification ${ }^{16}$. Microscopically, well-differentiated Sertoli-Leydig cell tumor consists of uniform solid or hollow tubular structures lined by Sertoli type cells. The intervening stroma contains variable numbers of Leydig cells. The latter tend to be packed in nests between the Sertoli cell tubules but may form more solid sheets in some tumors. Mitosis were rare in these tumors ${ }^{15}$.

SLCT has a non specific appearance. On USG, these tumors usually present either as a distinct hypo echoic mass or a heterogeneous mass that is primarily solid with multiple cystic spaces. Small virilizing SLCTs may be easily detected using Color Doppler US rather TVS alone 6,17,18. On CT images, a soft tissue attenuating adnexal mass is usually seen ${ }^{9}$. The solid tumor portions characteristically exhibit avid contrast uptake.

On MRI, the T2 signals of the solid components differ according to the extent of fibrous components. Nonetheless, strong hypo intensity on T2-weighted images is not characteristic ${ }^{5,6}$. Hypo intense areas on T1-weighted images and hyper intense areas on T2-weighted images reflect cystic areas. Cysts may also exhibit mild hyper intensity on T1-weighted images ${ }^{19}$.

In our case, the patient presented with severe pain and lump in the lower abdomen and USG revealed ovarian tumor, so provisional diagnosis was twisted ovarian tumor and emergency laparotomy was done at evening period. The patient gave the history of primary amenorrhea and on clinical examination secondary sex characters was well developed. On bi-manual and digital rectal examination cervix was absent and uterus could not be well delineated. USG also could not delineate the uterus properly. Tumor markers could not be carried out as facilities were not available in the hospital and the patient was too poor to afford the cost privately.

After confirmation of SLCT on histopathology, patient was advised to consultant oncologist for further management but the patient was non-compliant for further treatment (chemotherapy) and follow-up. Unfortunately the patient died after two months of operation which was known when we tried to contact patient over telephone for follow-up. A study showed that five patients died of the disease; four had received first treatment. The study also showed 5 year overall survival was $100 \%$ for patients with $\mathrm{G} 1$ disease and $77.8 \%$ for G2-3. In the same study, 5 year overall survival was $92.3 \%$ for stage 1 and $33.3 \%$ for stage $\geq 2^{20}$.

\section{Conclusion:}

Ovarian sex cord-stromal tumors are infrequent tumors that differ considerably from the more frequent epithelial ovarian tumors. The rarity of sex cord-stromal tumor contributes to a low index of suspicion; therefore, a thorough knowledge of the clinicopathologic and advanced radiologic and imaging findings of these tumors is important. The prognosis of patients with grade 1 SLCT is excellent without adjuvant chemotherapy and that of advanced stage or grade 2-3 tumors appear to benefit from postoperative chemotherapy.

\section{References:}

1. Haroon S, Zia A, Idrees R, Memon A, Fatima S, Kayani N. Clinicopathological spectrum of ovarian sex cord-stromal tumors; 20 years retrospective study in a developing country. $\mathrm{J}$ Ovarian Res. 2013;6:87. http://dx.doi.org/ 10.1186/1757-2215-6-87. [PMC free article] [PubMed]

2. Shim SH, Kim DY, Lee SW, et al.Laparoscopic management of early-stage malignant nonepithelial ovarian tumors: surgical and survival outcomes. Int J Gynecol Cancer. 2013;23:249255. http://dx.doi.org/10.1097//GC0b013e 318272e754. [PubMed]

3. Jung SE, Rha SE, Lee JM, et al. CT and MRI findings of sex cord-stromal tumor of the ovary. Am J Roentgenol. 2005; 185:207-215. http:// dx.doi.org/10.2213/ajr.185.1.01850207. [PubMed]

4. Pratt J. Pathology of the ovary. $1^{\text {st }}$ ed. Philadelphia: Sounders; 2004.pp.197-226. 
5. Tanaka YO, Tsunoda H, Kitagawa Y, Ueno T, Yoshikawa H, Saida Y. Functioning ovarian tumors: direct and indirect findings at MRI imaging. Radiographics. 2004; 24:S147166 .http://dx.doi.org/10.1148/ rg.24si045501.[PubMed]

6. Outwater EK, Wagner BJ, Mannion C, McLarney JK, Kim B. Sex cord-stromal and steroid cell tumors of the ovary. Radiographics. 1998;18:1523-1546.http://dx.doi.org/10.1148/ radiographics.18.6.9821198.[PubMed]

7. Caringella A, Loizzi V, Resta L, Ferreri R, Loverro G. A case of a Sertoli-Leydig Cell tumor in a postmenopausal women. Int. J Gynecol Cancer. 2006;16:435-438.http://dx.doi.org/ 10.1111/j.1525-1438.2006.00203.x.[PubMed]

8. Nicoletto MO, Caltarossa E, Donach M, Naedelli GB, Parenti A, Ambrosini A. Sertoli cell tumor: a rare case in an elderly patient. Eur $\mathrm{J}$ Gynecol Oncol. 2006;27:86-87.[PubMed]

9. Hricak H. Fibrothecoma and Sclerosing Stromal Tumor. In: Hricak H, Akin O, Sala E, Ascher SM, Levine D, Reinhold C, editors. Diagnostic Imaging: Gynecology. $1^{\text {st }}$ ed. Salt Lake City: Amirsys;2007.pp.728-731.

10. Bhat RA, Lim YK, Chia YN, Yam KL. SertoliLeydig cell tumor of the ovary: analysis of a single institution database. J Obstet Gynecol Res. 2013;39:305-310.http://dx.doi.org/10.1111/ j.1447-0756.2012.01928.x.[PubMed]

11. Sigismondi C, Gdducci A, Lorusso D, et al. Ovarian Sertoli-Leydig cell tumors. A retrospective MITO study. Gynecol Oncol. 2012;125:673-676. http://dx.doi.org/10.1046/ j.ygyno.2012.03.024.[PubMed]

12. A Chalvardjian and R.E.Scully, "Slerosing stromal tumors of the ovary," Cancer. 1973; 31(3):664-670.
13. Young RH, Scully RE, Ovarian Sertoli-Leydig cell tumors. A clinicopathological analysis of 207 cases. Am J Surg Pathol. 1985 Aug.9(8):54369. [medline]

14. Scully RE, Young RH, Clement PB. Tumors of the Ovary, Maldeveloped Gonads, Fallopian tube, and Atlas of Tumor Pathology. Third Series. Washington, DC: Armed Forces Institute of Pathology; 1998.

15. Lantzsch T, Stoerer S, Lawrenz K, Buchmann J, Strauss HG, Koelbl H. Sertoli-Leydig cell tumor. Arch Gynecol Obstet. 2001 Jan. 264(4):206-8. [medline]

16. Latthe T. Shafi MI, Rollason TP. Recurrence of Sertoli-Leydig cell tumor in contralateral ovary. Case report and review of literature. Eur $\mathrm{J}$ Gynecol Oncol. 2000. 21(1):62-3. [medline].

17. Outwater EK, Marchetto B, Wagner BJ. Virilizing tumors of the ovary: imaging features. Ultrasound Obstet Gynecol. 2000;15:365371.http://dx.doi.org/10,1046/j.14690705.2000.00123.x. [PubMed]

18. Yanushpolsky EH, Brow DL, Smith BL. Localization of small ovarian Sertoli-Leydig cell tumors by transvaginal sonography with color Doppler. Ultrasound Obstet Gynecol.1995;5:133135. http://dx.doi.org/10.1046/j.14690705.1995.05020133.x. [PubMed]

19. Hamm B, Forstner R, Baert AL, Knauth $M$, Sartor K. MRI and CT of female pelvis. New York: Springer; 2007. CT and MRI in ovarian carcinoma; p. 258.

20. Cristina S, Angiola G, Domenica L, Massimo C, Enrico B, Francesco R, Gennaro C, Marco M, Giorgia M. Ovarian Sertoli-Leydig cell tumors. A retrospective MITO study. http://dx.doi.org/ 10.1016/j.ygyno.2012.03.024. 